\title{
The role of CYBA (p22phox) and catalase genetic polymorphisms and their possible epistatic interaction in cervical cancer
}

\author{
Stephanie Anais Castaldo • Alda Pereira da Silva • \\ Andreia Matos • Ângela Inácio • Manuel Bicho • \\ Rui Medeiros • Irina Alho • Maria Clara Bicho
}

Received: 6 August 2014 / Accepted: 5 October 2014 /Published online: 12 October 2014

(C) International Society of Oncology and BioMarkers (ISOBM) 2014

\begin{abstract}
Human papillomavirus (HPV) infection is necessary but not a sufficient cause for the development of invasive cervical cancer (ICC). Epithelial tissues, target for HPV, are exposed to reactive oxygen species (ROS) associated with tumor initiation and progression. The NADPH oxidase (NOX) and catalase (CAT) are involved in hydrogen peroxide $\left(\mathrm{H}_{2} \mathrm{O}_{2}\right)$ production and inactivation, respectively. P22phox is the NOX subunit encoded by the CYBA gene that has a functional polymorphism (C-242T). This protein is involved in the regulation of electron transfer to oxygen. CAT is a hemic enzyme that plays a role in regulating $\mathrm{H}_{2} \mathrm{O}_{2}$ concentration, with a functional polymorphism $(\mathrm{C}-262 \mathrm{~T})$ in its gene. We evaluated CYBA $\mathrm{C}-242 \mathrm{~T}$ and $C A T \mathrm{C} 262 \mathrm{~T}$ genetic polymorphisms and their interaction in 132 women with ICC. We found that CYBA $C-242 \mathrm{~T}$ and $C A T \mathrm{C} 262 \mathrm{~T}$ genotype frequencies were
\end{abstract}

S. A. Castaldo $(\bowtie) \cdot$ A. P. da Silva $\cdot$ A. Matos $\cdot$ Â. Inácio $\cdot$

M. Bicho • M. C. Bicho

Genetics Laboratory and Environmental Health Institute, Faculty of

Medicine, University of Lisbon, Avenida Prof. Egas Moniz,

1649-028 Lisbon, Portugal

e-mail: nany.castaldo@gmail.com

S. A. Castaldo $\cdot$ M. C. Bicho

Dermatology Research Unit, Instituto de Medicina Molecular,

Faculdade de Medicina da Universidade de Lisboa, Lisbon, Portugal

Â. Inácio $\cdot$ M. Bicho

Instituto de Investigação Científica Bento da Rocha Cabral, Lisbon, Portugal

\section{R. Medeiros}

Molecular Oncology Group, Portuguese Institute of Oncology, Porto Centre, Porto, Portugal

I. Alho

Clinical and Translational Oncology Research Unit, Instituto de Medicina Molecular, Faculdade de Medicina da Universidade de Lisboa, Lisbon, Portugal significantly different between ICC and controls $\left(\chi^{2}\right.$ test, $p=0.017$ and $p=0.009$, respectively). Women with the $\mathrm{C} / \mathrm{T}$ CYBA-242 genotype had a lower risk for ICC development (odds ratio $(\mathrm{OR})=0.515,95 \%$ confidence interval (CI) $0.291-0.914, p=0.023)$ whereas T/T CAT-262 genotype carriers present an increased risk for ICC $(\mathrm{OR}=3.034$, $95 \%$ CI $1.462-6.298, p=0.003)$. Women with $\mathrm{C} / \mathrm{C}$ genotype for CYBA and T/T genotype for CAT had an increased risk to develop ICC comparing with the interaction of the other possible genotypes of both genes $(\mathrm{OR}=$ $3.952,95 \%$ CI $1.075-14.521, p=0.032)$. The CYBA $\mathrm{C}-242 \mathrm{~T}$ and $C A T \mathrm{C}-262 \mathrm{~T}$ genetic polymorphisms and their epistatic interactions can be associated with ICC through mechanisms related with the role of ROS in cell proliferation and apoptosis.

Keywords Oxidative stress $\cdot$ Cervical cancer $\cdot$ CYBA (p22phox) $\cdot$ Catalase $\cdot$ Polymorphism

\section{Introduction}

Human papillomavirus (HPV) infection is a necessary but not sufficient cause for the development of invasive cervical carcinoma (ICC). In addition to the viral genotype, the involvement of other factors is also important in the process of infection, transformation, cell immortalization, and tumor progression [1].

Epithelial tissues, the target for HPV infection, are heavily exposed to oxidative stress (OS) [2]. This has been associated with tumors through the exposure to reactive oxygen species (ROS) not balanced by antioxidants, promoting carcinogenesis and metastatic signaling. Thus, HPV and OS can act synergistically as two powerful initiating and promoting carcinogens. It has 
been shown that the viral infection, its chronic persistent infection, and the viral genome integration in the host cell are indeed potentiated by OS [2, 3]. ROS also have a key role on intercellular induction of apoptosis by signaling components and by targeting tumor cells. This signaling is mainly made through the hypochlorous $(\mathrm{HOCl})$ acid pathway, which depends on the generation of superoxide $\left(\mathrm{O}_{2} \cdot\right)$ anions by a membrane-associated NADPH oxidase (NOX) in transformed cells. $\mathrm{O}_{2} \cdot$ spontaneous and catalytic dismutation by superoxide dismutase (SOD) increases the production of hydrogen peroxide $\left(\mathrm{H}_{2} \mathrm{O}_{2}\right)$, which is used for the synthesis of $\mathrm{HOCl}$ through the catalyses of myeloperoxidase (MPO). Ultimately, $\mathrm{HOCl}$ and $\mathrm{O}_{2}$. interaction will generate apoptosis-inducing hydroxyl radicals [2, 4-7].

The NOX and catalase (CAT) are important enzymes involved in the production and dismutation of ROS [4]. NOX are membrane-associated multi-proteins that produce $\mathrm{O}_{2} \cdot$ for host defense and other functions [3, 8]. Generation of extracellular $\mathrm{O}_{2}$. through NOX is associated with oncogene activation and seems to be required for the control of cell proliferation and maintenance of the transformed state $(3,8)$. This protein consists of a regulatory $22-\mathrm{kDa} \alpha-$ subunit (p22phox) and a 91-kDa catalytic $\beta$-subunit (gp91phox). The p22phox protein is the NOX element responsible for the regulation of electron transfer to gp91phox $[5,9,10]$. In humans, the CYBA gene, located on chromosome $16 \mathrm{q} 24$, which codifies this protein, has up to 177 polymorphisms that seem to be involved in the expression and activity of NOX. The rs4673 polymorphism (C-242T) causes a functional nonconservative substitution from histidine-72 to a tyrosine residue that decreases its activity [11, 12].

Moreover, CAT is a heme enzyme that plays a predominant role in controlling hydrogen peroxide $\left(\mathrm{H}_{2} \mathrm{O}_{2}\right)$ concentration, by converting $\mathrm{H}_{2} \mathrm{O}_{2}$ into $\mathrm{H}_{2} \mathrm{O}$ and $\mathrm{O}_{2}$, protecting in this way cells from deleterious effects of OS [13]. They are typically homotetrameric with either small subunits or large subunits associated with heme. The active center of CAT consists of a heme group buried inside the molecular tetramer [14]. In humans, the $C A T$ gene is located on chromosome $11 \mathrm{p} 13$ and the rs1001179 polymorphism (C-262T) of this gene is located on the promoter region and influences transcription factors binding thus altering the basal transcription and consequent expression of this enzyme and hence the oxidative status of cells and its microenvironment [15].

To date, there is no genetic study that associates these proteins polymorphisms with the risk of developing ICC. Thus, the main objective of this work focuses on the study of the contribution of the functional polymorphisms of CYBA (rs4673) and $C A T$ (rs1001179) individually and in combination for the development of ICC.

\section{Materials and methods}

\section{Subjects}

This investigation was performed as part of a case-control study about the influence of functional candidate genes in ICC. Written informed consent was obtained from all participants. We studied 132 women with ICC, between the ages of 19 and 77 years old (mean \pm SD of $45.01 \pm 13.069$ years old; median age, 44.5 years old). They were randomly selected from (north and south) Portuguese Institute for Oncology Hospitals (IPO) outpatient populations, studied between 1996 and 2003. All women performed cytologic and histopathologic analyses. The cervical samples were obtained for HPV detection, which was done by polymerase chain reaction and hybridization methods using commercially available kits or as reported previously [16].

The ICC group was compared to a total of 242 healthy Caucasian female controls involved in a program of exercise from the Faculty of Sport and Exercise Sciences of Lisbon Technical University, whose mean age was $50.29 \pm 14.86$ years old, median age 55.0 years old (range, 18 and 79 years old).

\section{Genomic DNA isolation}

Whole blood samples were obtained from the patients and the controls. Genomic DNA was isolated from total blood samples, using a nonenzymatic method adapted from D.K. Lahiri and J.I. Nurnberger Jr. (1991) method [17].

\section{Genotyping the CYBA (p22phox) gene}

Polymorphic regions were amplified by polymerase chain reaction (PCR) in a $25-\mu l$ reaction mixture consisting of PCR Nucleotide Mix (Thermo Scientific ${ }^{\circledR}$ DreamTaq Green) containing $10 \mathrm{mM}$ dNTPs, $1.5 \mathrm{mM} \mathrm{MgCl}_{2}, 1 \mathrm{U}$ Taq polymerase; $10 \mathrm{mM}$ of each primer; and $200 \mathrm{ng}$ of genomic DNA. To amplify the 348-bp polymorphic region of the CYBA gene, we used the following primers: forward primer $5^{\prime}$ TGCTTGTG GGTAAACCAAGGCCGGTG 3' and reverse primer 5' AACACTGAGGTAAGTGGGGGTGGCTCCGT 3', followed by digestion with RsaI that recognizes the nucleotide sequence GTAC. PCR conditions involved an initial denaturation of DNA at $94{ }^{\circ} \mathrm{C}$ for $2 \mathrm{~min}$, followed by 35 cycles of amplification at $94{ }^{\circ} \mathrm{C}$ for $45 \mathrm{~s}$ (melting), $54{ }^{\circ} \mathrm{C}$ for $1 \mathrm{~min}$ (annealing), and $72{ }^{\circ} \mathrm{C}$ for $30 \mathrm{~s}$, and final extension at $72{ }^{\circ} \mathrm{C}$ for $10 \mathrm{~min}$. The resulting product was digested with the restriction endonuclease at $37{ }^{\circ} \mathrm{C}$ for $16 \mathrm{~h}$ according to the manufacturer's instructions, and digestion products were analyzed following electrophoresis in $3 \%$ agarose gel stained with ethidium bromide $(10 \mu \mathrm{g} / \mathrm{ml})$. Restriction enzyme digestion results in a 348-bp product (allele C) or a 188-and 160-bp product (allele $\mathrm{T}$ ). The genotypes for this polymorphism will be represented by $\mathrm{C} / \mathrm{C}$ or $\mathrm{C} / \mathrm{T}$ or $\mathrm{T} / \mathrm{T}$. 


\section{Genotyping the CAT gene}

Polymorphic regions were amplified by polymerase chain reaction (PCR) in a $25-\mu 1$ reaction mixture consisting of PCR Nucleotide Mix (Thermo Scientific ${ }^{\circledR}$ DreamTaq Green) containing $10 \mathrm{mM}$ dNTPs, $1.5 \mathrm{mM} \mathrm{MgCl}_{2}, 1 \mathrm{U}$ Taq polymerase; $10 \mathrm{mM}$ of each primer; and $200 \mathrm{ng}$ of genomic DNA. To amplify the 185-bp polymorphic region of the CAT gene, we used the following primers: forward primer $5^{\prime}$ AGAGCCTC GCCCCGCCGGACCG $3^{\prime}$ and reverse primer 5' TAAGAG CTGAGAAAGCATAGCT 3', followed by digestion with SmaI that recognizes the nucleotide sequence CCCGGG. PCR conditions involved an initial denaturation of DNA at $94{ }^{\circ} \mathrm{C}$ for $2 \mathrm{~min}$, followed by 5 cycles of amplification at $94{ }^{\circ} \mathrm{C}$ for $1 \mathrm{~min}$ (melting), $52^{\circ} \mathrm{C}$ for $1 \mathrm{~min}$ (annealing), and $72{ }^{\circ} \mathrm{C}$ for $1 \mathrm{~min}$, and 35 more cycles of amplification at $94^{\circ} \mathrm{C}$ for $30 \mathrm{~s}$, $52{ }^{\circ} \mathrm{C}$ for $30 \mathrm{~s}$, and $72{ }^{\circ} \mathrm{C}$ for $30 \mathrm{~s}$ and final extension at $72{ }^{\circ} \mathrm{C}$ for $10 \mathrm{~min}$. The resulting product was digested with the restriction endonuclease at $30^{\circ} \mathrm{C}$ for $16 \mathrm{~h}$ according to the manufacturer's recommendations, and digestion products were analyzed following electrophoresis in $3 \%$ agarose gel stained with ethidium bromide $(10 \mu \mathrm{g} / \mathrm{ml})$. Restriction enzyme digestion results in a 185-bp product (allele T) or a 155- and 30-bp product (allele C). The genotypes for this polymorphism will be represented by $\mathrm{C} / \mathrm{C}$ or $\mathrm{C} / \mathrm{T}$ or $\mathrm{T} / \mathrm{T}$.

\section{Statistical analysis}

All statistical analyses were performed using the IBM SPSS Statistics version 20.

Observed genotype frequencies were tested for deviation from Hardy-Weinberg equilibrium with the chi-square goodness-of-fit test $\left(\dot{\div}^{2}\right)$. This test was also used to evaluate the significant differences between the two populations, in order to know if the odds ratio (OR) test was justifiable. OR for ICC risk and the corresponding $95 \%$ confidence intervals (CI) were calculated using logistic regression analysis adjusted for age. This test was applied to each polymorphism to analyze its risk factor individually; it was also applied to the association of both polymorphisms to analyze the functional possible epistatic relation between the genes of this enzymes and how it may affect the risk for ICC. $p$ values $<0.05$ were considered statistically significant.

\section{Results}

We performed the determination of CYBA C-242T (rs4673) and CAT C-262T (rs1001179) polymorphisms in 132 women with ICC and 242 healthy Caucasian female controls.
Table 1 The frequency distributions of allele and genotype for $C Y B A$ C-242T (rs4673) and CAT C-262 T (rs1001179) genetic polymorphisms among ICC patients and controls

\begin{tabular}{lllll}
\hline Polymorphism & & Controls & ICC & $p$ value \\
\hline CYBA C-242T & & $n=153$ & $n=100$ & \\
Genotype & $\mathrm{C} / \mathrm{C}$ & $54(35.3 \%)$ & $48(48 \%)$ & 0.017 \\
& $\mathrm{C} / \mathrm{T}$ & $90(58.8 \%)$ & $41(41 \%)$ & \\
& $\mathrm{T} / \mathrm{T}$ & $9(5.9 \%)$ & $11(11 \%)$ & \\
Allele & $\mathrm{C}$ & $99(64.7 \%)$ & $69(68.5 \%)$ & $0.432^{\text {n.s }}$ \\
& $\mathrm{T}$ & $54(35.3 \%)$ & $31(31.5 \%)$ & \\
CAT C-262T & & $n=107$ & $n=120$ & \\
Genotype & $\mathrm{C} / \mathrm{C}$ & $65(61.3 \%)$ & $58(48.7 \%)$ & 0.009 \\
& $\mathrm{C} / \mathrm{T}$ & $27(25.5 \%)$ & $25(21 \%)$ & \\
Allele & $\mathrm{T} / \mathrm{T}$ & $14(13.2 \%)$ & $36(30.3 \%)$ & \\
& $\mathrm{C}$ & $79(74.1 \%)$ & $71(59.2 \%)$ & 0.001 \\
& $\mathrm{~T}$ & $28(25.9 \%)$ & $49(40.8 \%)$ & \\
\hline
\end{tabular}

The values for the genotypes and respective allele frequencies represent absolute frequencies (relative frequencies, \%)

n.s Nonsignificant $p$ value

The CYBA (p22phox) genotype and ICC risk

Allele and genotype frequencies of subjects for the C-242T polymorphism on the CYBA gene are shown in Table 1. The genotype distributions in controls were not in HardyWeinberg equilibrium $\left(\chi^{2}=6.919, p=0.031\right)$. The genotype was available from 100 patients and 153 controls. Genotype frequencies were $35.3 \%$ for $\mathrm{C} / \mathrm{C}, 58.8 \%$ for $\mathrm{C} / \mathrm{T}$, and $5.9 \%$ for $\mathrm{T} / \mathrm{T}$ in the control group and $48 \%$ for $\mathrm{C} / \mathrm{C}, 41 \%$ for $\mathrm{C} / \mathrm{T}$, and $11 \%$ for $\mathrm{T} / \mathrm{T}$ among the ICC patients. We observed a significant difference in genotype distributions of $C Y B A$ C242T polymorphism between ICC patients and the controls, being the $\mathrm{C} / \mathrm{T}$ genotype more frequent in the control group $(p=0.017)$.

Individuals carrying the $\mathrm{C} / \mathrm{T}$ genotype were 0.515 -fold at a lower risk of developing ICC compared with those having homozygous $\mathrm{C} / \mathrm{C}$ and $\mathrm{T} / \mathrm{T}$ genotypes $(p=0.023)$ (Table 2 ).

\section{The CAT genotype and ICC risk}

Allele and genotype frequencies of the subjects for the C-262T polymorphism on the CAT gene are shown in Table 1 .

Table 2 Risk analysis from odds ratios adjusted for age CYBA C-242T (rs4673) genotypes between ICC and controls

\begin{tabular}{llllll}
\hline Genotype & Controls (\%) & Patients (\%) & OR & $95 \%$ CI & $p$ value \\
\hline $\mathrm{C} / \mathrm{C}$ & $54(35.3)$ & $48(48)$ & Ref. & - & - \\
$\mathrm{C} / \mathrm{T}$ & $90(58.8)$ & $41(41)$ & 0.515 & $0.291-0.914$ & 0.023 \\
$\mathrm{~T} / \mathrm{T}$ & $9(5.9)$ & $11(11)$ & 1.252 & $0.452-3.471$ & $0.665^{\text {n.s }}$ \\
\hline
\end{tabular}

n.s Nonsignificant $p$ value 
Table 3 Risk analysis from odds ratios adjusted for age for CAT C-262T (rs1001179) genotypes between ICC and controls

\begin{tabular}{llllll}
\hline Genotype & Controls (\%) & Patients (\%) & OR & $95 \% \mathrm{CI}$ & $p$ value \\
\hline $\mathrm{C} / \mathrm{C}$ & $65(61.3 \%)$ & $58(48.7 \%)$ & Ref. & - & - \\
$\mathrm{C} / \mathrm{T}$ & $27(25.5 \%)$ & $25(21 \%)$ & 1.00 & $0.514-1.944$ & $1.00^{\mathrm{n} . \mathrm{s}}$ \\
$\mathrm{T} / \mathrm{T}$ & $14(13.2 \%)$ & $36(30.3 \%)$ & 3.034 & $6.298-11.462$ & 0.003 \\
\hline
\end{tabular}

n.s Nonsignificant $p$ value

The genotype distributions in controls were consistent with Hardy-Weinberg equilibrium $\left(\chi^{2}=4.557, p=0.102\right)$. The genotype was available from 119 patients and 106 controls. Genotype frequencies were $61.3 \%$ for $\mathrm{C} / \mathrm{C}, 25.5 \%$ for $\mathrm{C} / \mathrm{T}$, and $13.2 \%$ for $\mathrm{T} / \mathrm{T}$ in the control group and $48.7 \%$ for $\mathrm{C} / \mathrm{C}$, $21 \%$ for $\mathrm{C} / \mathrm{T}$, and $30.3 \%$ for $\mathrm{T} / \mathrm{T}$ among the patients. We observed a significant difference in genotype distributions of CAT C-262T polymorphism between ICC patients and controls, being the $\mathrm{T} / \mathrm{T}$ genotype more frequent in the ICC group $(p=0.009)$.

Individuals carrying the $\mathrm{T} / \mathrm{T}$ genotype were 3.034 fold at a higher risk of developing ICC compared with having the $\mathrm{C}$ allele ( $\mathrm{C} / \mathrm{C}$ and $\mathrm{C} / \mathrm{T}$ genotypes). The other genotypes did not show any relative risk associated with the disease (Table 3).

Epistatic relations between the CYBA (p22phox) and CAT inferred from their functional polymorphisms

As it is known, the NOX and CAT enzymes are closely related and work in metabolic sequence, it is important to examine if its functional polymorphisms in association of genotypes change the risk to develop ICC for the carriers. The $\div^{2}$ test demonstrated that women with ICC have a tendency for a significant difference from the control population $(\div 2=$ 13,995, $p=0.082$ ). In Table 4, it is shown the different associations between $C Y B A$ and $C A T$ polymorphisms and the OR value for each (shown only the significant value). It is shown in Table 4 that the highest risk for ICC is the association of $\mathrm{C} / \mathrm{C}$ and $\mathrm{T} / \mathrm{T}$ genotypes for $C Y B A$ and $C A T$ genetic polymorphisms, respectively, compared with all other possible genotypes $(\mathrm{OR}=3.952 ; 95 \% \mathrm{CI}=1.075-14.521 ; p=0.032)$.

\section{Discussion and conclusions}

This is the first work that unravels the association between CYBA (rs4673) and CAT (rs1001179) genetic polymorphisms in cervical cancer. In this work, we studied the clinical relevance of CYBA C-242T (rs4673) and CAT C-262T (rs1001179) functional genetic polymorphisms in ICC. Our results show a decreased risk in developing ICC for individuals with the $\mathrm{C} / \mathrm{T}$ genotype of the $C Y B A$ gene and an increased risk with the T/T genotype of $C A T$ gene. When we evaluated the interaction of these genetic polymorphisms, we found a greater risk in developing ICC for individuals with the $\mathrm{C} / \mathrm{C}$ genotype of CYBA (p22phox) and T/T genotype of CAT gene.

It has been demonstrated that ROS, namely $\mathrm{H}_{2} \mathrm{O}_{2}$, has a role as a second messenger molecule in signaling cascades that regulates gene expression and fundamental cellular processes such as proliferation, differentiation, and migration $[8$, 18]. $\mathrm{H}_{2} \mathrm{O}_{2}$ role in tumorigenesis has been investigated showing the existence of an abnormal regulation of ROS in this pathology. Normal cells have a wide antioxidant regulatory defense system that serves to prevent the oxidative stress and the development of neoplasms [3, 19-21].

The groups of women studied had a different age distribution $(p=0.000)$ and to counteract and reduce this difference, we conducted an age-adjusted statistical analysis. In this study, the women from the control group had a higher average age than the women from the patient group, and as it is known, age is a risk factor for ICC. So, we must take into account that they had more time to develop cancer if they had a persistent infection by oncogenic HPVs, counteracting this age risk effect.

One of the aims of this study was to determine whether the C-242T polymorphism of the CYBA gene is associated with susceptibility for the ICC development. To do so, we performed a case-control study on the known polymorphism of CYBA gene in women with ICC compared with healthy control samples. It is known that the $\mathrm{C}-242 \mathrm{~T}$ polymorphism causes a non-synonymous substitution; however, the role of the 242T allele has not yet been clarified: Guzik et al. [22] assert that this mutation is associated with a reduced NADPH oxidase(NOX) activity so there is less production of ROS. However, Schreiber et al. [12] describe an increased oxidase activity, resulting in increased production of ROS. There are several studies characterizing and relating this polymorphism

Table 4 Risk analysis of the interactions between C-262T CYBA (rs 1001179) and CAT C262T CAT (rs4673) genetic polymorphisms in ICC

\begin{tabular}{llllr}
\hline CYBA/CAT & Controls (\%) & Patients (\%) & OR & $95 \%$ CI \\
\hline Other genotypes $^{\mathrm{a}}$ & $82(96.5 \%)$ & $83(87.4 \%)$ & 0.253 & $0.069-0.930$ \\
T/T and C/C & $3(3.5 \%)$ & $12(12.6 \%)$ & 3.952 & $1.075-14.521$ \\
\hline
\end{tabular}

${ }^{a}$ Other genotypes, $\mathrm{C} / \mathrm{C}$ and $\mathrm{C} / \mathrm{C} ; \mathrm{C} / \mathrm{C}$ and $\mathrm{C} / \mathrm{T} ; \mathrm{C} / \mathrm{C}$ and $\mathrm{T} / \mathrm{T} ; \mathrm{C} / \mathrm{T}$ and $\mathrm{C} / \mathrm{C} ; \mathrm{C} / \mathrm{T}$ and $\mathrm{C} / \mathrm{T} ; \mathrm{C} / \mathrm{T}$ and T/T; T/T and C/T; T/T and T/T 
with other pathologies; however, the association with ICC is not yet known [23]. In our study, the risk analysis showed that the heterozygote genotype acts as a protective factor $(\mathrm{OR}=$ $0.515,95 \%$ CI $0.291-0.914)$. On the other hand, if we study the OR for this polymorphism not adjusted for age, we will find a greater risk of developing ICC associated with the homozygote genotypes on the p22phox CYBA gene (OR $\mathrm{C} / \mathrm{C}=1.692,95 \% \mathrm{CI} 1.013-2.829$ and $\mathrm{OR} \mathrm{T} / \mathrm{T}=2.983$, $95 \%$ CI 1.175-7.573; data not shown), causing a phenomenon called heterosis. Molecular heterosis may be based on an $\mathrm{U}$ type curve response, where there is a higher activity allele and a lower activity one [24]. In this case, the homozygote genotype $\mathrm{C} / \mathrm{C}$ leads to increased ROS production, mainly $\mathrm{H}_{2} \mathrm{O}_{2}$ resulting from dismutation of $\mathrm{O}_{2}$, which in turn results in excessive cell growth; on the other hand, the homozygote genotype T/T lowers ROS production, mainly decreasing $\mathrm{O}_{2}$. apoptotic cell capacity, resulting in a higher risk for the development of tumors in both cases [6]. This phenomenon makes the heterozygote $\mathrm{C} / \mathrm{T}$ genotype a protecting factor for cancer. Thus, this study demonstrates a relationship between the C242T polymorphism in protecting against the development of ICC.

The other aim of this study was to determine whether the C-262T polymorphism of the CAT gene is associated with susceptibility for the ICC development. To do so, we developed a similar approach to that used to study the CYBA polymorphism, namely a case-control study on the known polymorphism of CAT gene in women with ICC and in a control sample. Although the importance of CAT has been established in a great number of pathologies related to its poor function, the association with ICC is not yet known [14]. In our study, the risk analysis showed a greater risk of developing ICC associated with the homozygote genotype $\mathrm{T} / \mathrm{T}(\mathrm{OR}=$ $3.034,95 \%$ CI 1.462-6.298). This result is in agreement with other works that showed association of the $\mathrm{T}$ variant of the C-262T polymorphism with decreased enzyme activity, generating high levels of ROS [25, 26].

Because NOX and CAT proteins work in sequence in a metabolic pathway, it is important to study polymorphism associations between them. In Table 4, it is shown that the association of the $\mathrm{C} / \mathrm{C}$ genotype of $C Y B A$ and the $\mathrm{T} / \mathrm{T}$ genotype of $C A T$ leads to a higher risk for ICC. This association is consistent with our previous data.

Resistance to intercellular ROS signaling characterizes tumor cells. This signaling is inhibited by a membraneassociated catalase that destroys $\mathrm{H}_{2} \mathrm{O}_{2}$ efficiently and prevents $\mathrm{HOCl}$ synthesis responsible for target-cell apoptosis. On the other hand, transformed cells, cells with activated oncogenes and the potential to form tumors, do not have this membraneassociated catalase, having a intracellular catalase instead, allowing ROS signaling and causing control system failure ultimately resulting in cell apoptosis. Therefore, consumption of $\mathrm{H}_{2} \mathrm{O}_{2}$ through membrane-associated catalase and a sufficient $\mathrm{O}_{2}$ anion generation seems to be the biochemical basis for tumor cell resistance against intercellular ROS mediated signaling $[5,6]$. The combination of active NOX, catalase, and SOD in the membrane of tumor cells represents a sophisticated mode for efficient protection of the tumor cells against apoptosis induction by their own ROS [7]. Thus, we suggest a possible epistatic relation between both genotypes, $\mathrm{C} / \mathrm{C}$ of CYBA and $\mathrm{T} / \mathrm{T}$ of CAT, possibly resulting in a lack of apoptotic signaling and excessive cell growth.

Finally, this study shows the hypothesis that those polymorphisms on pro- or antioxidant enzyme genes results in a weak antioxidant defense, producing higher concentration of ROS, which translates on a higher risk of tumor development. Our study supports this hypothesis, where a higher concentration of ROS produced as a consequence of both C-242T CYBA and C-262T CAT genetic polymorphisms is associated with a higher risk for developing ICC.

Acknowledgments The authors would like to thank the Instituto de Investigação Científica Bento da Rocha Cabral for financial support regarding the determination of $\mathrm{C}-242 \mathrm{~T} C Y B A$ and $\mathrm{C}-262 \mathrm{~T} C A T$ genetic polymorphisms.

Conflicts of interest None

\section{References}

1. Muñoz N, Castellsagué X, de González AB, Gissmann L. Chapter 1: HPV in the etiology of human cancer. Vaccine. 2006;31(24 Suppl 3): $\mathrm{S} 3 / 1-10$.

2. De Marco F. Oxidative stress and HPV carcinogenesis. Viruses. 2013;5(2):708-31.

3. Wu W-S. The signaling mechanism of ROS in tumor progression. Cancer Metastasis Rev. 2006;25(4):695-705.

4. Laurent A, Nicco C, Chéreau C, Goulvestre C, Alexandre J, Alves A, et al. Controlling tumor growth by modulating endogenous production of reactive oxygen species. Cancer Res. 2005;65(3):948-56.

5. Bechtel W, Bauer G. Catalase protects tumor cells from apoptosis induction by intercellular ROS signaling. Anticancer Res. 2009;29(11):4541-57.

6. Bechtel W, Bauer G. Modulation of intercellular ROS signaling of human tumor cells. Anticancer Res. 2009;29(11):4559-70.

7. Bauer G. Targeting extracellular ROS signaling of tumor cells. Anticancer Res. 2014;34(4):1467-82.

8. Lambeth JD. Nox enzymes, ROS, and chronic disease: an example of antagonistic pleiotropy. Free Radic Biol Med. 2007;43(3):332-47.

9. Sardina JL, López-Ruano G, Sánchez-Abarca LI, Pérez-Simón JA, Gaztelumendi A, Trigueros C, et al. p22phox-dependent NADPH oxidase activity is required for megakaryocytic differentiation. Cell Death Differ. 2010;17(12):1842-54.

10. Ushio-fukai M, Zafari AM, Fukui T, Ishizaka N, Griendling KK. p22phox is a critical component of the superoxide-generating NADH/NADPH oxidase system and regulates angiotensin IIinduced hypertrophy in vascular smooth muscle cells*. J Biol Chem. 1996;271(38):23317-21.

11. Najafi M, Alipoor B, Shabani M, Amirfarhangi A, Ghasemi H. Association between rs4673 (C/T) and rs $13306294(\mathrm{~A} / \mathrm{G})$ haplotypes 
of $\mathrm{NAD}(\mathrm{P}) \mathrm{H}$ oxidase p22phox gene and severity of stenosis in coronary arteries. Gene. 2012;499(1):213-7.

12. Schreiber R, Ferreira-Sae MC, Ronchi J A, Pio-Magalhães J A, Cipolli J A, Matos-Souza JR, et al. The C242T polymorphism of the p22-phox gene (CYBA) is associated with higher left ventricular mass in Brazilian hypertensive patients. BMC Med Genet. BioMed Central Ltd; 2011;12(1): 114.

13. Chang D, Hu ZL, Zhang L, Zhao YS, Meng QH, Guan QB, et al. Association of catalase genotype with oxidative stress in the predication of colorectal cancer: modification by epidemiological factors. Biomed Environ Sci. 2012;25(2):156-62.

14. Chelikani P, Ramana T, Radhakrishnan TM. Catalase: a repertoire of unusual features. Indian $\mathrm{J}$ Clin Biochem. 2005;20(2):131-5.

15. Khodayari S, Salehi Z, Asl SF, Aminian K, Mirzaei Gisomi N, Dalivandan ST. Catalase gene C-262T polymorphism: importance in ulcerative colitis. J Gastroenterol Hepatol. 2013;28(5):819-22.

16. Matos A, Moutinho J, Pinto D, Medeiros R. The influence of smoking and other cofactors on the time to onset to cervical cancer in a southern European population. Eur J Cancer Prev. 2005;14(5): 485-91.

17. Lahiri DK, Nurnberger JI. A rapid non-enzymatic method for the preparation of HMW DNA from blood for RFLP studies. Nucleic Acids Res. 1991;19(19):5444.

18. Mesquita FS, Dyer SN, Heinrich DA, Bulun SE, Marsh EE, Nowak RA. Reactive oxygen species mediate mitogenic growth factor signaling pathways in human leiomyoma smooth muscle cells. Biol Reprod. 2010;82(2):341-51.

19. Manda G, Nechifor MT, Neagu T-M. Reactive oxygen species, cancer and anti-cancer therapies. Curr Chem Biol [Internet]. 2009;3(1):342-66.

20. Behrend L, Henderson G, Zwacka R. Molecular mechanisms of signalling molecular mechanisms of signalling transformation. Biochem Soc Trans. 2003;31(6):1441-4.

21. Pelicano H, Carney D, Huang P. ROS stress in cancer cells and therapeutic implications. Drug Resist Updat. 2004;7(2):97-110.

22. Guzik TJ, West NEJ, Black E, McDonald D, Ratnatunga C, Pillai R, et al. Functional effect of the C242T polymorphism in the $\mathrm{NAD}(\mathrm{P}) \mathrm{H}$ oxidase p22phox gene on vascular superoxide production in atherosclerosis. 2000;102(15):1744-7.

23. Wu Z, Lou Y, Jin W, Liu Y, Lu L, Chen Q, et al. Relationship of the p22phox (CYBA) gene polymorphism C242T with risk of coronary artery disease: a meta-analysis. PLoS One. 2013;8(9):e70885.

24. Comings DE, MacMurray JP. Molecular heterosis: a review. Mol Genet Metab. 2000;71(1-2):19-31.

25. Fabre E, Raynaud-Simon A, Golmard J, Hebert M, Dulcire X, Succari M, et al. Gene polymorphisms of oxidative stress enzymes: prediction of elderly renutrition. Am J Clin Nutr. 2008;4:1504-12.

26. Funke S, Risch A, Nieters A, Hoffmeister M, Stegmaier C, Seiler $\mathrm{CM}$, et al. Genetic polymorphisms in genes related to oxidative stress (GSTP1, GSTM1, GSTT1, CAT, MnSOD, MPO, eNOS) and survival of rectal cancer patients after radiotherapy. J Cancer Epidemiol. 2009;2009:302047. 